\title{
Aortic stiffness in type-1 diabetes mellitus; beware of hypertension
}

\author{
E. E. van der Wall • H. M. Siebelink • \\ A. J. Scholte • M. J. Schalij
}

Received: 8 March 2011/Accepted: 10 March 2011/Published online: 26 March 2011

(C) The Author(s) 2011. This article is published with open access at Springerlink.com

Over the past years considerable progress has been made in the field of cardiovascular magnetic resonance (CMR), providing accurate evaluation of left ventricular mass, volumes and function [1-9]. CMR has shown unique abilities in characterizing myocardial tissue composition. In particular, high-resolution contrast-enhanced CMR has been used to visualize myocardial fibrosis with a high accuracy [10-16]. For instance, in patients with acute myocardial infarction, the injured myocardium shows increased CMR contrast compared to normal myocardium when imaged by delayed gadolinium enhancement. The transmural extent of delayed gadolinium enhancement predicts functional outcome after interventional procedures performed in patients with acute myocardial infarction and chronic ischemic heart disease [16-21]. Not only in the setting of an acute myocardial infarction, but also in patients with various manifestations of cardiomyopathy, evidence of delayed gadolinium enhancement may have important clinical and prognostic implications [22-30]. Magnetic resonance angiography (MRA) has been

Editorial comment on to the article of Brandts et al. (doi: 10.1007/s10554-011-9841-2).

E. E. van der Wall $(\bowtie) \cdot$ H. M. Siebelink ·

A. J. Scholte · M. J. Schalij

Department of Cardiology, Leiden University Medical

Center, P.O. Box 9600, Leiden, Netherlands

e-mail: e.e.van_der_wall@lumc.nl introduced as a method that can provide visualization of all three major coronary arteries, coronary bypasses and the aorta within a single three-dimensional acquisition [31-40]. CMR has become the first choice imaging modality in complex congenital heart disease and imaging great vessels [41-46]. In particular, CMR has proven to be of indispensable value in identifying aortic stiffness in Marfan patients using pulse wave velocity measurements $[47,48]$. In these patients pulse wave velocity is the propagation speed of the pressure or flow wave front traveling along the aorta. For instance, it has been shown that aortic stiffness in Marfan syndrome, together with mean blood pressure, is reduced by beta-blocker therapy, and CMR is well suited to detect these changes by measuring aortic distensibility and pulse wave velocity.

In the present issue of the International Journal of Cardiovascular Imaging, Brandts et al. [49] investigated in type-1 diabetes mellitus patients the role of hypertension and of diabetes mellitus itself on aortic stiffness by using CMR. The hypothesis of the study was that hypertension has a predominant effect on aortic stiffness in type- 1 diabetes mellitus patients. In addition, it was established to what extent type-1 diabetes mellitus itself independently adds to aortic stiffness. Subjects were divided into 4 groups: 32 healthy volunteers, 20 diabetes mellitus patients, 31 hypertensive patients, and 28 patients with both diabetes mellitus and hypertension. Aortic stiffness was measured by means of pulse wave velocity using 
velocity-encoded CMR (Medis, Leiden). Mean aortic pulse wave velocity was $5.7 \pm 1.2 \mathrm{~m} / \mathrm{s}$ in healthy volunteers, $5.9 \pm 1.2 \mathrm{~m} / \mathrm{s}$ in diabetes mellitus patients without hypertension, $7.3 \pm 1.2 \mathrm{~m} / \mathrm{s}$ in hypertensive patients, and $7.3 \pm 1.3 \mathrm{~m} / \mathrm{s}$ in patients with both diabetes mellitus and hypertension. Compared to healthy control subjects, aortic pulse wave velocity was significantly higher in patients with hypertension and in patients with both diabetes mellitus and hypertension. However, aortic pulse wave velocity was not increased in patients having diabetes mellitus alone. The authors concluded that hypertension has a predominant contributive effect on aortic stiffness in diabetes mellitus patients whereas the direct diabetic effect on aortic stiffness was insignificant.

The main finding of the study was that the independent effect of type-1 diabetes mellitus on aortic pulse wave velocity was minor; aortic pulse wave velocity was not significantly different between healthy volunteers and type- 1 diabetes mellitus patients. Secondly, the independent effect of hypertension on aortic pulse wave velocity was most important; aortic pulse wave velocity was significantly higher in hypertensive patients than in healthy volunteers. In addition, the combination of type- 1 diabetes mellitus and hypertension resulted in increased aortic stiffness, and was significantly higher than in patients having type-1 diabetes mellitus alone. Interestingly, the authors showed that aortic stiffness in type-1 diabetes patients mainly depends on having additional hypertension, and not on diabetes alone. Therefore, identification of hypertension in patients with type-1 diabetes is of importance for risk stratification and can be used for guiding therapy in order to improve cardiovascular outcome.

Investigating the hypertensive contribution on aortic stiffness in patients with type-1 diabetes mellitus is utmost relevant for cardiovascular risk assessment as type-1 diabetes mellitus is often associated with hypertension. The current study is unique in the sense that it used CMR-assessed pulse wave velocity measurements. More recent studies from the same group showed that stiffness of the aorta was independently associated with systolic left ventricular function [50]. In addition, aortic stiffness independently predicted white matter brain atrophy in patients with type-1 diabetes mellitus [51].

In summary, the study by Brandts et al. [49], using CMR-determined pulse wave velocity measurements, convincingly demonstrates that hypertension has a predominant contributive effect on aortic stiffness in diabetes mellitus type-1 patients, whereas the direct diabetic effect on aortic stiffness was very small. Since aortic stiffness and diabetes mellitus are highly associated with adverse cardiovascular events, identifying hypertension in diabetes mellitus type-1 patients seems utmost relevant for further risk stratification.

\section{Conflict of interest None.}

Open Access This article is distributed under the terms of the Creative Commons Attribution Noncommercial License which permits any noncommercial use, distribution, and reproduction in any medium, provided the original author(s) and source are credited.

\section{References}

1. de Roos A, Matheijssen NA, Doornbos J, van Dijkman PR, van Rugge PR, van der Wall EE (1991) Myocardial infarct sizing and assessment of reperfusion by magnetic resonance imaging: a review. Int J Card Imaging 7:133-138

2. van Rugge FP, Boreel JJ, van der Wall EE et al (1991) Cardiac first-pass and myocardial perfusion in normal subjects assessed by sub-second Gd-DTPA enhanced MR imaging. J Comput Assist Tomogr 15:959-965

3. van der Wall, Vliegen HW, de Roos A, Bruschke AV (1995) Magnetic resonance imaging in coronary artery disease. Circulation 92:2723-2739

4. Dirksen MS, Bax JJ, de Roos A et al (2002) Usefulness of dynamic multislice computed tomography of left ventricular function in unstable angina pectoris and comparison with echocardiography. Am J Cardiol 90:1157-1160

5. van Rugge FP, van der Wall EE, Bruschke AV (1992) New developments in pharmacologic stress imaging. Am Heart J 124:468-485

6. van Rugge FP, van der Wall EE, van Dijkman PR, Louwerenburg HW, de Roos A, Bruschke AV (1992) Usefulness of ultrafast magnetic resonance imaging in healed myocardial infarction. Am J Cardiol 70:1233-1237

7. Matheijssen NA, Louwerenburg HW, van Rugge FP et al (1996) Comparison of ultrafast dipyridamole magnetic resonance imaging with dipyridamole SestaMIBI SPECT for detection of perfusion abnormalities in patients with one-vessel coronary artery disease: assessment by quantitative model fitting. Magn Reson Med 35:221-228

8. van der Wall EE, Heidendal GA, den Hollander W, Westera G, Roos JP (1981) Metabolic myocardial imaging with 123I-labeled heptadecanoic acid in patients with angina pectoris. Eur J Nucl Med 6:391-396

9. Holman ER, van Jonbergen HP, van Dijkman PR, van der Laarse A, de Roos A, van der Wall EE (1993) Comparison of magnetic resonance imaging studies with enzymatic 
indexes of myocardial necrosis for quantification of myocardial infarct size. Am J Cardiol 71:1036-1040

10. Matheijssen NA, Baur LH, Reiber JH et al (1996) Assessment of left ventricular volume and mass by cine magnetic resonance imaging in patients with anterior myocardial infarction intra-observer and inter-observer variability on contour detection. Int $\mathrm{J}$ Card Imaging 12:11-19

11. van der Geest RJ, Niezen RA, van der Wall EE, de Roos A, Reiber JH (1998) Automated measurement of volume flow in the ascending aorta using MR velocity maps: evaluation of inter- and intraobserver variability in healthy volunteers. J Comput Assist Tomogr 22:904-911

12. Nemes A, Geleijnse ML, van Geuns RJ et al (2008) Dobutamine stress MRI versus threedimensional contrast echocardiography: it's all black and white. Neth Heart J $16: 217-218$

13. van der Wall EE, van Dijkman PR, de Roos A et al (1990) Diagnostic significance of gadolinium-DTPA (diethylenetriamine penta-acetic acid) enhanced magnetic resonance imaging in thrombolytic treatment for acute myocardial infarction: its potential in assessing reperfusion. Br Heart $\mathbf{J}$ 63:12-17

14. Nijveldt R, Beek AM, Hirsch A et al (2008) 'No-reflow' after acute myocardial infarction: direct visualisation of microvascular obstruction by gadolinium enhanced CMR. Neth Heart J 16:179-181

15. Oemrawsingh PV, Mintz GS, Schalij MJ, Zwinderman AH, Jukema JW, van der Wall EE (2003) Intravascular ultrasound guidance improves angiographic and clinical outcome of stent implantation for long coronary artery stenoses: final results of a randomized comparison with angiographic guidance (TULIP Study). Circulation 107:62-67

16. van Dijkman PR, van der Wall EE, de Roos A et al (1991) Acute, subacute, and chronic myocardial infarction: quantitative analysis of gadolinium-enhanced MR images. Radiology 180:147-151

17. van der Wall EE, den Hollander W, Heidendal GA, Westera G, Majid PA, Roos JP (1981) Dynamic myocardial scintigraphy with 123 I-labeled free fatty acids in patients with myocardial infarction. Eur J Nucl Med 6:383-389

18. van der Laarse A, Kerkhof PL, Vermeer F et al (1988) Relation between infarct size and left ventricular performance assessed in patients with first acute myocardial infarction randomized to intracoronary thrombolytic therapy or to conventional treatment. Am J Cardiol 61:1-7

19. Torn M, Bollen WL, van der Meer FJ, van der Wall EE, Rosendaal FR (2005) Risks of oral anticoagulant therapy with increasing age. Arch Intern Med 165:1527-1532

20. de Roos A, Matheijssen NA, Doornbos J, van Dijkman PR, van Voorthuisen AE, van der Wall EE (1990) Myocardial infarct size after reperfusion therapy: assessment with GdDTPA-enhanced MR imaging. Radiology 176:517-521

21. Slart RH, Bax JJ, van Veldhuisen DJ, van der Wall EE, Dierckx RA, Jager PL (2006) Imaging techniques in nuclear cardiology for the assessment of myocardial viability. Int J Cardiovasc Imaging 22:63-80

22. van der Wall EE, Heidendal GA, den Hollander W, Westera G, Roos JP (1980) I-123 labeled hexadecenoic acid in comparison with thallium-201 for myocardial imaging in coronary heart disease. A preliminary study. Eur J Nucl Med 5:401-405

23. Underwood SR, Bax JJ, vom Dahl J et al (2004) Study Group of the European Society of Cardiology. Imaging techniques for the assessment of myocardial hibernation. Report of a Study Group of the European Society of Cardiology. Eur Heart J 25:815-836

24. Groothuis JG, Beek AM, Meijerink MR, Brinckman SL, Hofman MB, van Rossum AC (2010) Towards a noninvasive anatomical and functional diagnostic work-up of patients with suspected coronary artery disease. Neth Heart J 18:270-273

25. Germans T, Nijveldt R, Brouwer WP et al (2010) The role of cardiac magnetic resonance imaging in differentiating the underlying causes of left ventricular hypertrophy. Neth Heart J 18:135-143

26. Lexis CP, Rahel BM, van Langen H et al (2010) Cardiac magnetic resonance imaging in daily practice in a peripheral medical centre: description of the first 383 patients. Neth Heart J 18:524-530

27. van der Wall EE (2009) Cardiac magnetic resonance: a safe procedure? Neth Heart J 17:363

28. Bakx AL, van der Wall EE, Braun S, Emanuelsson H, Bruschke AV, Kobrin I (1995) Effects of the new calcium antagonist mibefradil (Ro 40-5967) on exercise duration in patients with chronic stable angina pectoris: a multicenter, placebo-controlled study. Ro 40-5967 International Study Group. Am Heart J 130:748-757

29. Schuijf JD, Bax JJ, van der Wall EE (2007) Anatomical and functional imaging techniques: basically similar or fundamentally different? Neth Heart J 15:43-44

30. de Roos A, Doornbos J, Luyten PR, Oosterwaal LJ, van der Wall EE, den Hollander JA (1992) Cardiac metabolism in patients with dilated and hypertrophic cardiomyopathy: assessment with proton-decoupled P-31 MR spectroscopy. J Magn Reson Imaging 2:711-719

31. Ten Cate FJ (2009) Cardiomyopathies: a revolution in molecular medicine and cardiac imaging. Neth Heart $\mathbf{J}$ 17:456-457

32. Portegies MC, Schmitt R, Kraaij CJ et al (1991) Lack of negative inotropic effects of the new calcium antagonist Ro 40-5967 in patients with stable angina pectoris. J Cardiovasc Pharmacol 18:746-751

33. Kaandorp TA, Lamb HJ, Viergever EP et al (2007) Scar tissue on contrast-enhanced MRI predicts left ventricular remodelling after acute infarction. Heart 93:375376

34. Schuijf JD, Bax JJ, van der Wall EE (2007) Anatomical and functional imaging techniques: basically similar or fundamentally different? Neth Heart J 15:43-44

35. Götte MJ, Rüssel IK, de Roest GJ et al (2010) Magnetic resonance imaging, pacemakers and implantable cardioverter-defibrillators: current situation and clinical perspective. Neth Heart J 18:31-37

36. Molhoek SG, Bax JJ, van Erven L et al (2004) Comparison of benefits from cardiac resynchronization therapy in patients with ischemic cardiomyopathy versus idiopathic dilated cardiomyopathy. Am J Cardiol 93:860-863

37. Tops LF, Schalij MJ, Holman ER, van Erven L, van der Wall EE, Bax JJ (2006) Right ventricular pacing can induce ventricular dyssynchrony in patients with atrial 
fibrillation after atrioventricular node ablation. J Am Coll Cardiol 48:1642-1648

38. Ypenburg C, Roes SD, Bleeker GB et al (2007) Effect of total scar burden on contrast-enhanced magnetic resonance imaging on response to cardiac resynchronization therapy. Am J Cardiol 99:657-660

39. Molhoek SG, van Erven L, Bootsma M, Steendijk P, van der Wall EE, Schalij MJ (2004) QRS duration and shortening to predict clinical response to cardiac resynchronization therapy in patients with end-stage heart failure. Pacing Clin Electrophysiol 27:308-313

40. Ypenburg C, van der Wall EE, Schalij MJ, Bax JJ (2008) Imaging in cardiac resynchronisation therapy. Neth Heart $\mathrm{J}$ 16:S36-S40

41. Bleeker GB, Schalij MJ, Van der Wall EE, Bax JJ (2006) Postero-lateral scar tissue resulting in non-response to cardiac resynchronization therapy. J Cardiovasc Electrophysiol 17:899-901

42. Germans T, Nijveldt R, Brouwer WP et al (2010) The role of cardiac magnetic resonance imaging in differentiating the underlying causes of left ventricular hypertrophy. Neth Heart J 18:135-143

43. van der Wall EE, Siebelink HM, Bax JJ (2010) Evaluation of hypertrophic cardiomyopathy: new horizons for CMR? Neth Heart J 18:116-117

44. Olimulder MA, van Es J, Galjee MA (2009) The importance of cardiac MRI as a diagnostic tool in viral myocarditis-induced cardiomyopathy. Neth Heart J 17:481-486

45. Niezen RA, Helbing WA, van der Wall EE, van der Geest RJ, Rebergen SA, de Roos A (1996) Biventricular systolic function and mass studied with MR imaging in children with pulmonary regurgitation after repair for tetralogy of Fallot. Radiology 201:135-140

46. Rebergen SA, Ottenkamp J, Doornbos J, van der Wall EE, Chin JG, de Roos A (1993) Postoperative pulmonary flow dynamics after Fontan surgery: assessment with nuclear magnetic resonance velocity mapping. J Am Coll Cardiol 21:123-131

47. Groenink M, Lohuis TA, Tijssen JG et al (1999) Survival and complication free survival in Marfan's syndrome: implications of current guidelines. Heart 82:499-504

48. Nollen GJ, Groenink M, Tijssen JG, van der Wall EE, Mulder BJ (2004) Aortic stiffness and diameter predict progressive aortic dilatation in patients with Marfan syndrome. Eur Heart J 25:1146-1152

49. Brandts A, van Elderen SG, Tamsma JT et al (2011) The effect of hypertension on aortic pulse wave velocity in type- 1 diabetes mellitus patients: assessment with MRI. Int J Cardiovasc Imaging. doi:10.1007/s10554-011-9841-2

50. van Elderen SG, Brandts A, Westenberg JJ et al (2010) Aortic stiffness is associated with cardiac function and cerebral small vessel disease in patients with type 1 diabetes mellitus: assessment by magnetic resonance imaging. Eur Radiol 20:1132-1138

51. van Elderen SG, Brandts A, van der Grond J et al (2011) Cerebral perfusion and aortic stiffness are independent predictors of white matter brain atrophy in type 1 diabetic patients assessed with magnetic resonance imaging. Diabetes Care 34:459-463 